\title{
傷寒論に学ぶ少陽病の病態と治療法
}

\author{
金子 幸夫 \\ 金子医院，三重，干514-0035 津市西丸之内12-3

\section{Pathogenesis and Treatment of Shao Yang Disease Learned in the Shang Han Lun}

Yukio KANEKO

KANEKO Clinic, 12-3 Nishimarunouchi, Tsu City, Mie 514-0035, Japan

\begin{abstract}
The Shaoyang lies next to the Interior of the Taiyang and to the Exterior of the Yangming, and is located in the half exterior and half interior position, containing both the parts and its physiological function which belong to the Gallbladder Channel of Foot-Shaoyang and the Triple Warmer Channel of Hand-Shaoyang. The Gallbladder Channel of Foot-Shaoyang controls the dispersing and discharging function of the vital energy (qi), and the Triple Warmer Channel of Hand-Shaoyang controls the function which distributes and transports the vital energy (qi), the fire and the water.When the wind-cold pathogen enters Shaoyang, anti-pathogenic vital-qi and exopathogen conflict each other,the distribution and the transport of the vital energy (qi), the fire and the water in the Triple Warmer Channel is obstructed due to the impairment of the dispersing and discharging function of the Gallbladder Channel of Foot-Shaoyang, the malfunction of Shaoyang pivots is then occured and results in the Shaoyang disease which is characteristic of the symptom complex such as bitter taste in the mouth, dryness of the throat,blurring of vision, alternate fever and chills, fullness in the chest and hypochondrium, hypochondria and anorexia, restless in mind, incessant vomiting, wiry and thready pulse and so on. This syndrome is treated by using Xiao chai fu tang which can harmonize Shaoyang. If various inproper treatments are given repeatedly to the Shaoyang disease, the syndrome to which Xiao chai hu tang must be given disappears, and a delirium as a deteriorated case appears newly, it is important to make clear what kind of inproper treatments were given, and the most appropriate treatment must be done in accordance with different present syndromes.
\end{abstract}

Key words : Shaoyang, Imbalance of the dispersing and discharging function, Obstructed distribution and transport of the vital energy (qi), the fire and the water, Malfunction of Shaoyang pivots, Xiao chai hu tang, Harmonizing Shaoyang, Treatment in accordance with different syndromes.

\section{要旨}

少陽は，太陽の表と陽明の裏に隣接して半表半裏に位置し，足少陽胆経と手少陽三焦経の経絡の所属する部位と その生理機能を包括する。足少陽胆は疏泄を主り，手少陽三焦は人体の気・火・水が布散し転輸する機能を主る。 風寒の邪が少陽に侵入し，邪気と正気が相互に争い，少陽胆の疏泄を主る機能が失調するために，三焦で気・火・ 水の布散と転輸が障害され，少陽枢機が不利になる場合は，口が苦い，咽が乾く，目が眩む，往来寒熱，胸脇苦満， 默黑として飲食を欲せず，心煩，喜嘔，脈弦細などの証候を特徵とする少陽病が発生する。本証の治療は，小柴胡 湯を用いて少陽を和解する。もし少陽病に誤治を重ね，柴胡の証が消失し，变証の譫語が出現する場合は，どのよ うな誤治を犯したのかを明らかにし，出現する証候に随ってこれを治療する。

キーワード : 少陽, 疏泄を主る機能の失調，気・火・水の布散と転輸の障害，少陽枢機不利，小柴胡湯，和解少 陽，随証治療

洟原 それでは学術奨励賞の発表会を開かせてい ただきます。いわゆる学会における学会賞というの
は，学会のメインイベントの 1 つであります。そj いう意味で, 金子先生の長年の研究の成果の発表を 
お願いし，先生の業績に対して我々は拍手を送りた いと思います。最初に金子先生のご経歴を述べさせ ていただきます。

先生は, 昭和47年に三重県立大学医学部を卒業さ れまして，49年に大学院第三内科に入局されました。 先生はそれ以来，臨床の場の内科という王道を歩い てこられましたが，その間にも金沢大学のがん研究 所等の研究者として, いわゆる純粋な研究者として の道も歩かれております。その後，53年に三重大学 医学部大学院を卒業されて, 同時に学位を取得され ております。

昭和55年から58年の 3 年間，ニューヨークのス ローン・ケタリング記念がん研究所の研究員として 研究にいそしんでおられました。その後，58年にニ ユーヨークから帰られまして, 再び第三内科の助手, 講師を務妨ら，60年に三重大学医学部附属病院の 腫瘍疾患診療部の助教授になられました。大学で内 科という場面で王道を歩いてこられましたが，平成 4 年，一念発起するところがたぶんあったと思われ ますが，開業されまして，現在に至って扔られます。 その間に研究の志を忘れず，今日ご発表になるよ うな内容のことをずっと続けてこられました。その ほかに, 平成 5 年から日本東洋医学会の専門医制度 の東海地区の委員長，11年度からは三重県の部会長 を務められております。現在は，東洋医学会の評議 員, 指導医, 専門医, 東洋医学会の福祉部長等を務 められております。母校の医学部の非常勤講師も務 められて抢ります。

先生は開業されてから，実験の場にたぶんなかな か携わることは難しかったと思いますが，いわゆる 古典の『傷寒論解説』, 『金貴要略解説』, 『傷寒六経 弁証解説』,『金實臟腑弁証解説』等の，いわゆる古 典の文献のいろいろな方面からの解釈をされまし て，4つの本の出版をされました。その成果が東洋 医学会で認められ，学術奨励賞が与えられたわけで す。先生，そのご苦労の一端をお話し願いたいと思 います。よろしく妳願いします。

\section{1 . はじめに}

只今御紹介頂きました金子でございます。まず始 めに, この度，日本東洋医学会奨励賞を受賞するに 当たり,このような素晴しい賞をお与え下さいまし た会長の石橋晃先生, 私が書きました《傷寒論》と 《金厦要略》に関する四冊の解説書に対して終始序
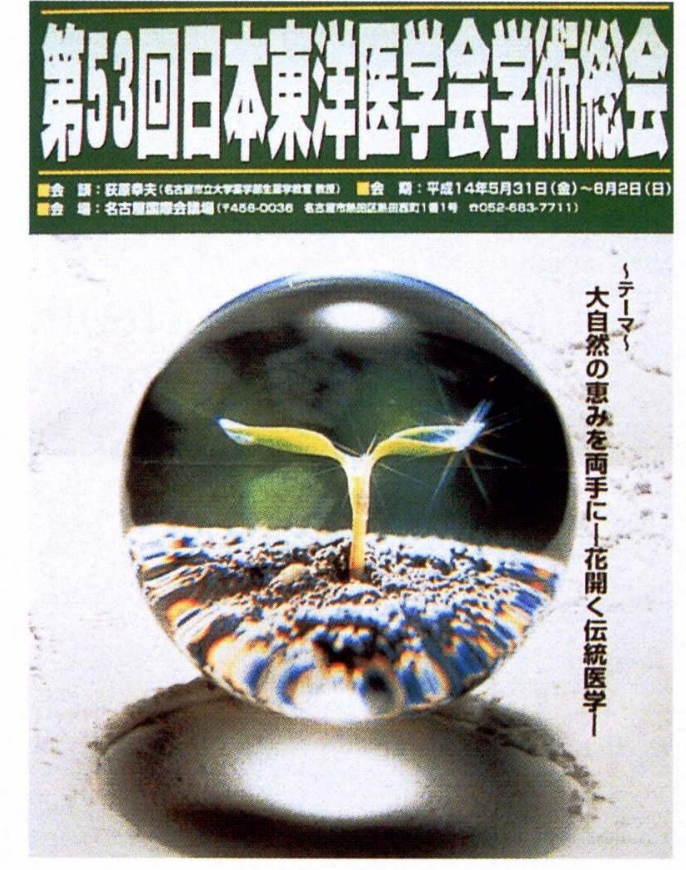

图 1

文を書いて下さいました松田邦夫先生と青山廉平先 生, 大会会頭の荻原幸夫先生, 準備委員長の佐藤祐 造先生，並びに御支援下さいました諸先生に心から 御礼申し上げます。

さて, 私は, 中医学の参考書を中心に《傷寒論》 と《金實要略》を読んでまいりました。そこで，本 日は,「傷寒論に学ぶ少陽病の病態と治療法」とい う演題で, 《傷寒論》の中から少陽病のどのような 病態を読み取ることができるのかについて括し申 し上げます。

\section{2. 中医学における《傷寒論》の考え方}

今日の中医学では, 《傷寒論》の六経病変は「臓 腑経絡気化学説」に従って理解されています。この 学説では,「邪が六経に侵入すると, 影響が該当す る経絡, 経絡の所属する臟腑に及び, 臓腑の生理機 能が失調する」と考えます。ここでいう「気化」は, 邪の侵襲を受けると, 経絡や臓腑の生理機能が失調 することを意味します。即ち，蔵腑経絡気化学説は, 経絡学説に立脚していますが, 最終的に経絡の所属 する臟腑の生理機能が失調することを最も重視して います。

\section{3. 傷寒を発症させる病邪}

傷寒を発症させる病邪は「風寒の邪」と称されま すが, 実際は寒邪が主体です。風寒の邪が人体に侵 入する最も初期の段階は「太陽病」と称され, 中風 


\section{少陽胆の疏泄を主る機能}

疏泄の意義:疏は、疏導、開通。泄は、発泄、発散

疏泄とは、気を通じ、発散し、伸びやかに生長発育し、 あるいは水の流れをよくする作用を言う。気を通じる作用 とは、体内では「全身の気の流れを上下·左右·内外に 円滑に行らせる機能である」と定義することができる。
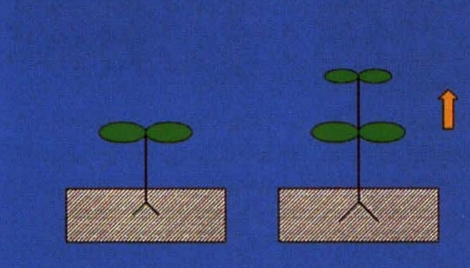

図 2

\section{少陽枢機と少陽枢機不利}

足少陽胆の疏泄を主る機能と手少陽三焦 の気・火・水を布散し転輸する機能は、「少陽 枢機」と総称される。

邪が少陽に侵入して邪正相争が発生し、少 陽胆の疏泄を主る機能が失調するために、三 焦で気・火·水の布散と転輸が障害される病 態は、「少陽枢機不利」と総称される。

图 3

と傷寒の 2 種類の病型に分類されます。一般に，正 気が旺盛である場合は傷寒に罹患し，正気が虚弱で ある場合は中風に罹患するとされています。ただ， 人によっては，ある時は中風に罹患し，またある時 は傷寒に罹患することがあるので，太陽病を発症さ せる病邪には 2 種類があると考えられます。

今，中風を発症させる病邪は，「風邪の偏盛した 風寒の邪」と定義します。風邪は陽邪であり, 直ち に化熱するので，発病すると同時に発熱し，また， 風の性は開泄するので，自汗が出ます。

一方，傷寒を発症させる病邪は，「寒邪の偏盛し た風寒の邪」と定義します。寒邪は陰邪であり，寒 の性は凝滞し, 衛陽が概遏されるので, 悪寒がし, また，営陰が㮾滞するので，体痛が出現します。

少陽病が発生する経路は，邪が太陽から少陽に伝 変する場合と, 邪が少陽に直中する場合の 2 種類が あります。そして太陽病の中風と傷寒は, いずれも 少陽病を発生します。

\section{三焦の気・火・水を布散し転輸する機能}

少陽胆の疏泄を主る機能が正常である場合は、病は少陽にない。
(1) 気
(2)火（少火
(3) 水

(気) $\rightarrow$ 気

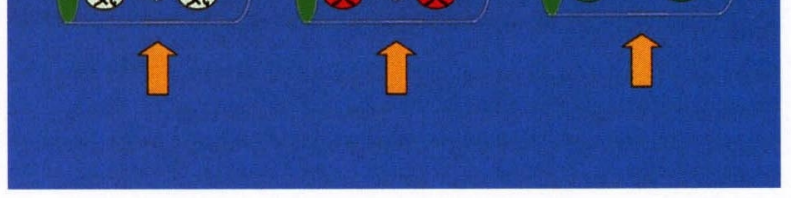

図 4

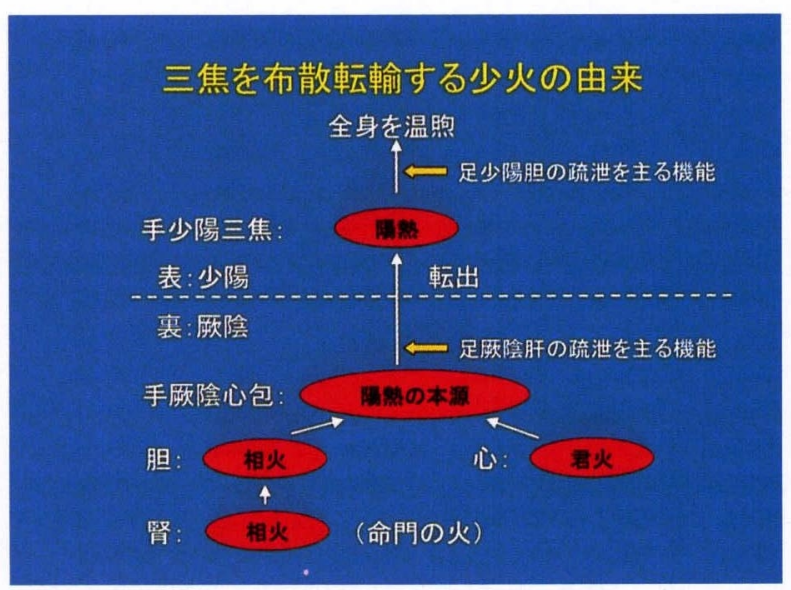

图 5

\section{4. 少陽}

（1）少陽の定義

少陽は，足少陽胆経と手少陽三焦経の経絡の所属 する部位とその生理機能を包括します。少陽は，太 陽の表に隣接し，陽明の裏に近接して半表半裏に位 置しています。足少陽胆は，相火を内に寄せ，条達

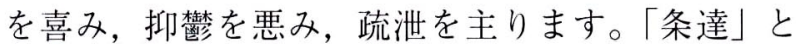
は，木の枝のように，気が四方に伸びて通じていく ことを言います。少陽胆の疏泄を主る機能は, 後で 説明します。手少陽三焦は, 人体の気・火・水が布 散し転輸する通路の機能を主ります。

\section{（2）少陽の概念}

この图 1 は，私達東海支部が主催しています第53 回日本東洋医学会学術総会のポスターの 1 つで, 先 生方のお手元にある学術総会講演要旨集の表紙を飾 る絵です。向かって右側には, 総会のメインテーマ 「大自然の恵みを両手に一花開く伝統医学一」と書 かれています。そしてポスターの中央では，芽が地 
中から顔を出し，2つの若葉を一杯に広げ, 大自然 から降り注ぐ恩恵を受けとめる形になっています。 吳謙等は, 《医宗金鑑》の中で「少陽は, 春を主る。 その気は, 半ばは地面の外に出ているが, 半ばは地 面の中にあり，人身の気もまたこのようである。そ こで, 半表半裏を主る」と述べ, 少陽はこのスライ ドにあるように地上に芽を出した若葉の状態にある と指摘しています。

(3) 少陽胆の疏泄を主る機能

次に少陽胆の疏涑を主る機能についてお話ししま す。疏洲の「疏」は疏導し開通することを意味し，

「泄」は発泄し発散することを意味します（図 2)。 即ち,「疏泄」とは, 気を通じ, 発散し, 草木を生 長発育し，あるいは水の流れをよくする作用を言い ます。少陽胆の疏泄を主る機能が正常である場合は, 地面より芽を出した若葉は上に向かってすくすくと 生長発育します。「気を通じる作用」とは, 体内で は「全身の気の流れを上下·左右・内外に円滑に行 らせる機能である」と定義することができます。

（4）少陽枢機と少陽枢機不利

足少陽胆の疏泄を主る機能と手少陽三焦の気・火 ・水を布散し転輸する機能は, 「少陽枢機」と総称 されます(图 3 )。即ち, 少陽枢機が正常に作用し ている場合は, 病は少陽にありません。一方, 邪が 少陽に侵入して邪正相争が発生し, 少陽胆の疏泄を 主る機能が失調するために, 三焦で気・火・水の布 散と転輸が障害される病態は,「少陽枢機不利」と 総称されます。即ち,「少陽枢機不利」は, 少陽病 を引き起こす病態そのものを言います。

\section{(5) 少陽枢機の語源}

「少陽枢機」という言葉は, 元々は《素問・陰陽 離合論》の「太陽を開と為し，陽明を闔と為し，少 陽を枢と為す」の中の「少陽を枢と為す」からきて います。張介賓は，《類経》の中で「少陽を枢とす るのは，陽気は表裏の間にあり，出ることができ， 入ることができるのが枢機のようであることを言 う」と注釈し，少陽は開き戸を開閉する「とぼそ」

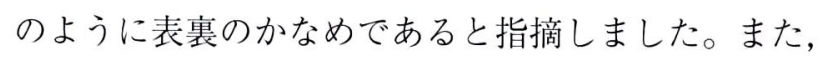
程応施は, 《傷寒論後条弁》の中で「少陽は, 六経 の中では開閭の枢機を典る。出る場合は陽であり, 入る場合は陰である。およそ客邪が侵入してその境 界に到達すると，毫気がこれによって中に起こる。 そこで, 半表半裏の邪と言う」と述べ, 少陽は人体

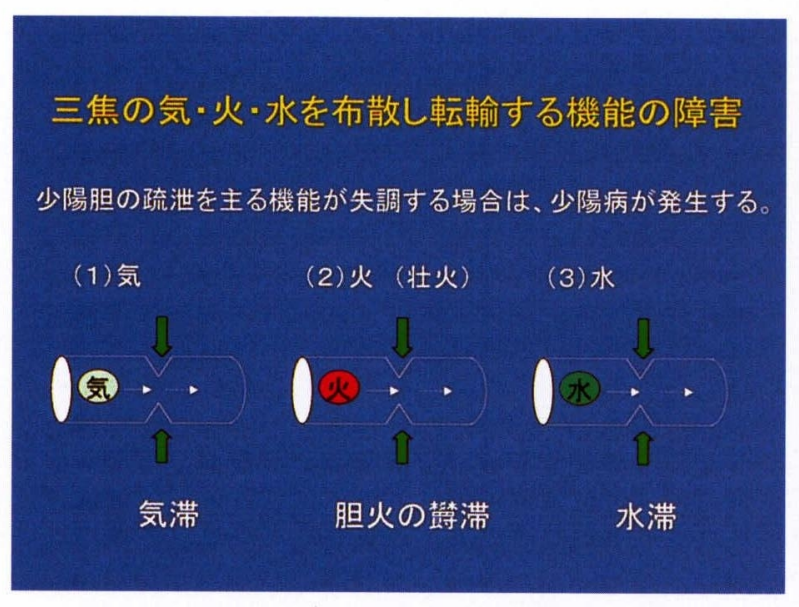

図 6

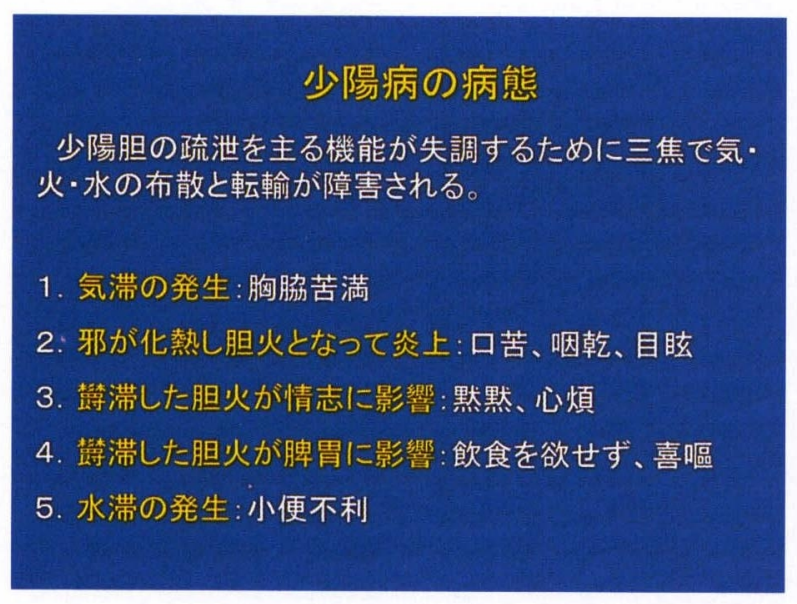

図 7

の半表半裏にあって邪気が出入する枢機を主るとし ました。枢機に関するこれらの解釈は, 枢機自体の 機能が明確でないので, 古典的な解釈のように思わ れます。

(6) 三焦の効能と形質の有無

三焦は, 人体の気・火・水が布散し転輸する通路 です。三焦の効能については, 《難経・三十一難》 に「三焦なる者は, 水穀の道路, 気の終始する所な り」, 《素問・霊蘭秘典論》に「三焦なる者は, 决瀆 の官, 水道出づ」とあるように, 水穀の気が出入し, 水液が運行する通路であると指摘されています。三 焦の形質の有無については, 《難経・二十五難》で は「心主と三焦は表重を為し，俱に有名にして無形 なり」とあるように，心包絡とともに名はあるが形 はないとされていますが, 《内経》では名もあり形 もあるとされています。例えば《霊枢・本輸篇》に いう「三焦なる者は, 中瀆の府なり。水道出づ」は, 張介賓の《類経》では「中瀆は, 川のようであり, 


\section{少陽病提綱}

\section{少陽の病為る、口苦く、咽乾き、目眩くなり。(263)}

病態: 風寒の邪が少陽経に直中し、少陽枢機が不利に なり、邪は麓遏されて化熱し、胆火となって清笅に咨上 する。

口苦し:胆火が炎上する。

咽乾く: 炎上した胆火が津液を灼傷する。

目眩く: 胆火が風を巻き込んで清嶡を乱す。

\section{図 8}

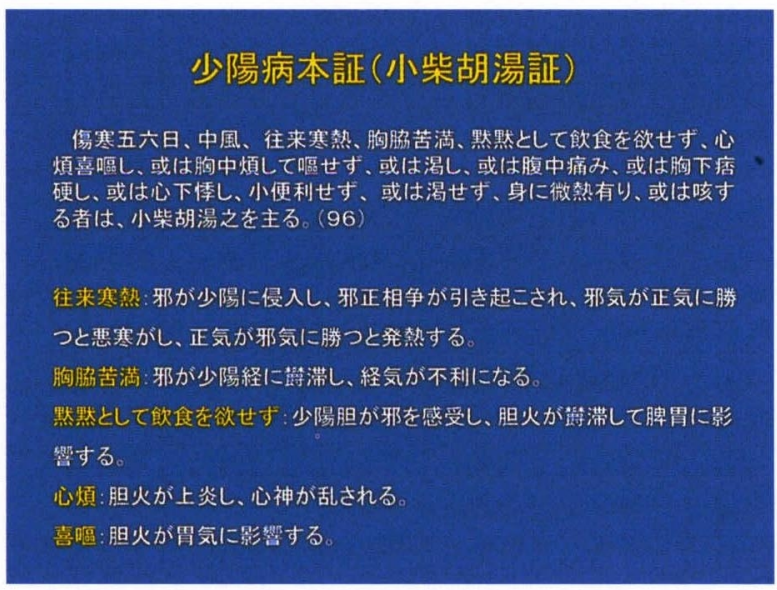

図 9

水道のようであり，源流が皆その中より出ることを 言う。思うに, 蔵腑の外, 身体の中で, 諸々の臓を 包み，内空の大きな腑である」と注釈され，三焦は 有形であると認識されています。ここでは，三焦は 有名でしかも有形であると理解します。

（7）三焦の気・火・水を布散し転輸する機能

三焦は，人体の気・火・水が布散し転輸していま す。今，少陽胆の疏泄を主る機能が正常である場合 は，病は少陽にありません。気・火・水は，三焦の それぞれの通路の中を，スライドでは左から右に向 かい，阻まれることなく流れてゆきます（图4）。 上に向かう矢印は, 少陽胆の疏泄を主る機能が正常 であることを示しました。ここでいう火，即ち「少 火」は，人体の生命活動を維持する正常の陽気であ り, 別の言葉で言えば，私達の身体をほほ $36.5^{\circ} \mathrm{C} に$ 温めている体温のことです。

（8）三焦を布散転輸する少火の由来

三焦を布散転輸し，人体の生命活動を維持する少
火は，手少陽三焦と表裏の関係にある手厥陰心包の 「陽熱の本源」に由来します（図 5 ）。楊育周氏の 《傷寒六経病変》によれば，手厥陰心包は心の君火 と腎と胆の二つの相火を集めて陽熱の本源とします。 この陽熱は, 足厥陰肝の疏泄を主る機能によって三 焦に転出されます。三焦に転出された陽熱は，足少 陽胆の疏泄を主る機能によって全身に送られてこれ を温めます。厥陰病では，足厥陰肝の疏泄を主る機 能が失調するので, 陽熱の本源が三焦に転出されず, その結果, 四肢の厥冷が出現します。一方, 少陽病 では，足厥陰肝の疏泄を主る機能が正常であるので, 四肢の厥冷は通常は出現しません。

\section{5 . 少陽病}

（1）三焦の気・次・水を布散し転輸する機能の障 害

少陽病に罹患し，少陽胆の疏泄を主る機能が失調 する場合は，気・灭・水の運行する通路が圧迫され て通じなくなります（图６）。気が榔滞する場合は， 気滞を生じます。火が㮾滞する場合は, 生命活動を 維持する火は正気を損傷する邪の火，即ち「壮火」 に変化し, 胆火の暨滞を生じます。水が節滞する場 合は，水滞を生じます。これが少陽病の発症する病 理機序です。

（2）少陽病の病態

少陽病の病態を要約します（图７）。少陽病では, 少陽胆の疏泄を主る機能が失調するために三焦で気 ・火・水の布散と転輸が障害されます。その結果, 1. 気滞の発生，2. 邪が化熱し胆火となって炎上， 3. 櫛滞した胆火が情志に影響，4.根滞した胆火が脾胃 に影響，5.水滞の発生などの病変が見られます。例 えば気滞が発生する場合は, 臨床症状としては胸脇 苦満が出現します。「口が苦い」以下の症状の詳細 は，条文を紹介する中で説明します。情志は，七情 と五志を指します。「胆火が情志に影響する」とい うのは，少陽病に罹患した場合に情緒が変動するこ とを言います。

(3) 少陽病提綱

第263条の「少陽の病為る, 口苦く, 咽乾き, 目 胘くなり」は, 少陽病に出現する最も重要な症状の いくつかを提示した少陽病提綱の条文です（图8）。 本証は，風寒の邪が少陽経に直中し，少陽枢機が不 利になり，邪は概遏されて化熱し，胆火となって清 篰に炎上した状態にあります。胆火が炎上すると， 
口は苦くなります。炎上した胆火が津液を灼傷する と, 咽が乾きます。胆火が風を巻き込んで清管を乱 すと, 目眩がします。

(4) 少陽病本証 (小柴胡湯証)

第96条の「傷寒五六日, 中風, 往来寒熱, 胸脇苦 満, 黙黙として飲食を欲せず，心煩喜嘔し，或は胸 中煩して嘔せず, 或は渴し, 或は腹中痛み, 或は胸 下㾂硬し, 或は心下悸し, 小便利せず，或は渇せず， 身に微熱有り, 或は咳する者は, 小柴胡湯之を主る」 は, 少陽病の最も典型的な病証を表した条文です（図 9)。本証は，太陽病の傷寒あるいは中風に罹患し て五六日が経過した後に発症しました。邪が太陽か ら少陽に侵入し，邪正相争が引き起こされ，邪気が 正気に勝つと悪寒がし, 正気が邪気に勝つと発熱し, 往来寒熱が出現します。邪が少陽経に爵滞し, 経気 が不利になると, 胸脇苦満が出現します。少陽胆が 邪を感受し, 胆火が概滞して脾胃に影響すると, 沈 黙して言葉を喋らず，食欲がなくなります。胆火が 上炎し, 心神が乱されると, 心煩が出現します。胆 火が胃気に影響すると, 喜嘔が出現します。これら は，少陽病では通常に見られる証候です。そこで， これらの証候が出現する場合は，小柴胡湯を用いて 治療します。一方,「或は胸中煩して嘔せず」より 以下の 7 種類の証候は, 半表半裏の中での邪の侵入 部位の違いや人体の素因の差異によって時に見られ る証候であり，「あるいは，そのようになる」とい う意味で「或然証」と称されています。或然証は, 小柴胡湯の加減方を用いて治療します。

(5) 少陽病の主症（九症）

少陽病の主症は，第263条の「口苦く，咽乾き， 目眩く」, 第96条の「往来寒熱, 胸脇苦満, 黙然々 して飲食を欲せず，心煩，喜嘔」，第265条の「脈弦 細」からなる 9 種類の証候を指し，「九症」と称さ れています (図10)。「脈弦細」の弦脈は病が少陽に あることを指し, 細脈は少陽病の発症に気血の不足 が関与することを指します。これら 9 種類の証候を 発症させる原因が少陽枢機不利です。第101条の「傷 寒中風，柴胡の証有るは，但だ一証を見わせば便ち 是なり。必ずしも悉くは具えず」は，太陽病の傷寒 あるいは中風に罹患した後，邪が太陽から少陽に伝 変し, 小柴胡湯証の主症が僅かに 1 種類出現した場 合は，直ちに小柴胡湯の適応になることを言います。

\section{6 . 小柴胡湯}

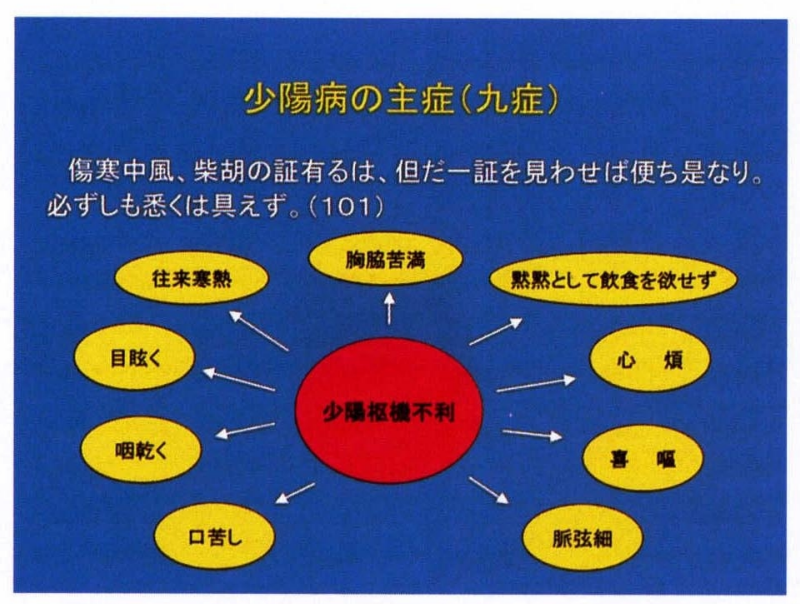

图10

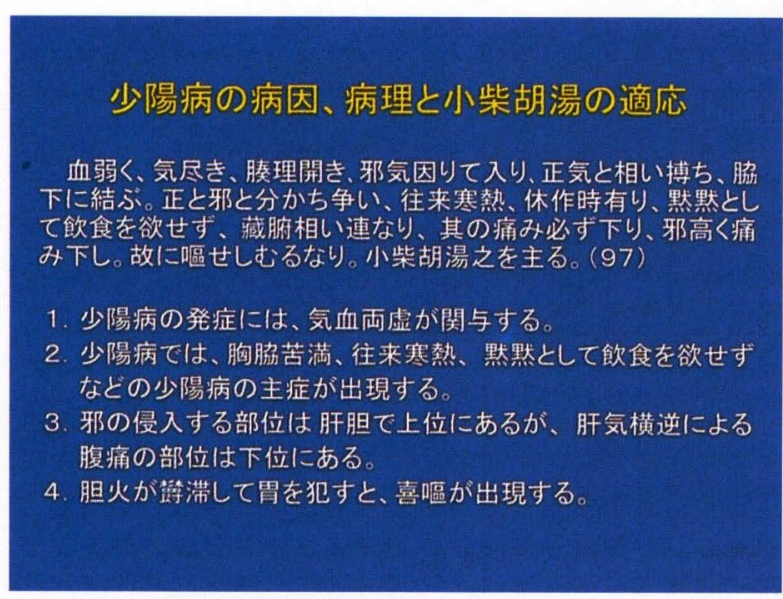

图11

（1） 小柴胡湯の効能

小柴胡湯は, 柴胡, 黄荅, 人参, 半夏, 甘草, 生 姜, 大策の七味からなります。その効能は, 「和解 少陽」と称されます。成無己は, 《傷寒明理論》の 中で「傷寒で邪気が表にある場合は, 必ず発汗して 体を汗で浸し, 邪気が裏にある場合は, 必ず下痢を させて邪気を除き去る。それが外ではなく,内でも なく, 半表半裏にある場合は, 既に発汗が好ましい 所でなく，また吐法や下法が対応する所でもない。 これは，和解するのがよいはずである。小柴胡湯は, 表裏を和解する方剤である」と述べています。劉渡 舟の《傷寒論辞典》では, 小柴胡湯の効能を「方中 の柴胡は邪を散じて表に透し, 半表の邪を外に宣ば す。黄芩は熱を除いて裏を清し, 半哓の邪を内に徹 す。人参，甘草は，正気を補い中焦を調和して邪を 除く。生姜, 大呆は, 甘草に配して営衛を調和し, 津液を行らせる」と説明しています。

(2) 小柴胡湯の中の人参と甘草 


\section{小柴胡湯と戦汗}

凡そ柴胡湯の病証にして之を下す。若し柴胡の証罷まざる 者は、復た柴胡湯を与う。必ず蒸蒸として振い、却って復た発 熱し汗出でて解す。(101)

1.小柴胡湯証は汗・吐・下が禁忌であるが、これを誤下すると、 正気が損傷される

2.もし小柴胡湯証が持続する場合は、また小柴胡湯を与える

3. 小柴胡湯を服用後、正気が薬力の助けを得て奮起して邪 に抵抗すると、先ず戦慄し、次いて熱気が沸き上がるよう に発熱し、最後に汗が出て病が解される。

\section{図12}

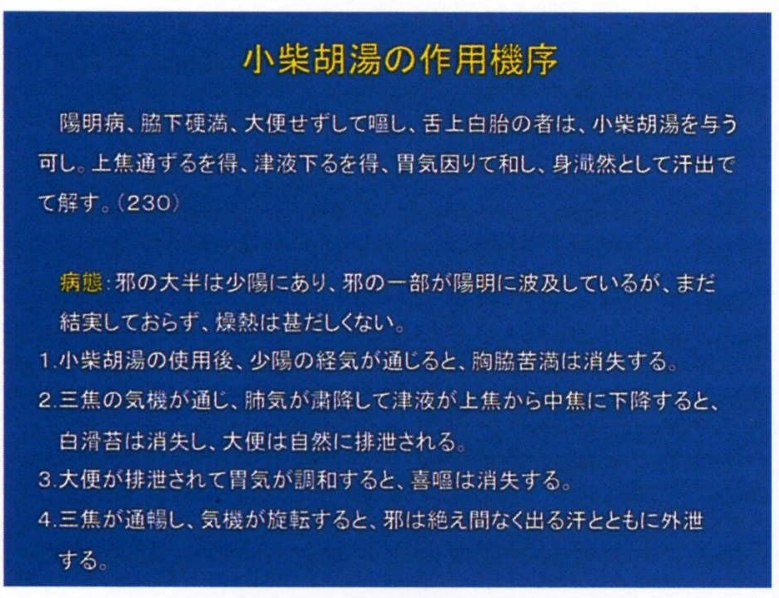

図13

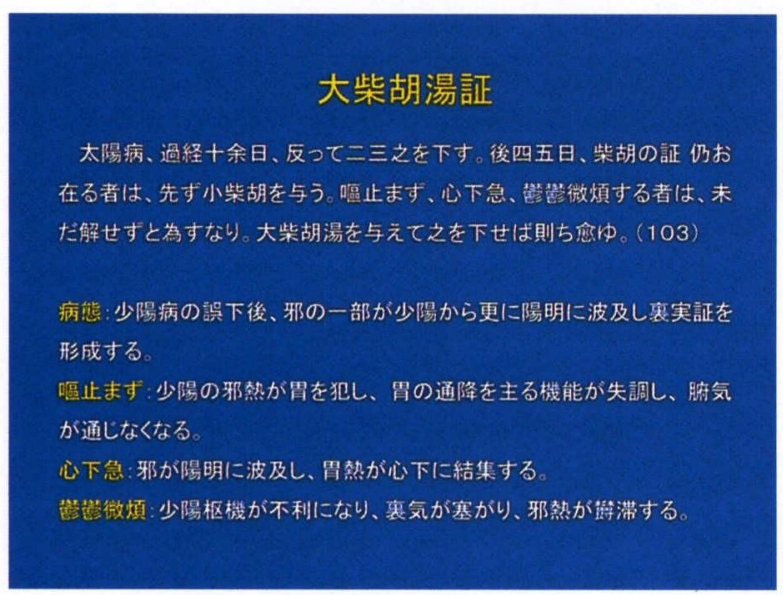

図14

小柴胡湯の中の人参と甘草の効能については，柯 韵伯は《傷寒来蘇集》の中で「人参と甘草は, 中気 を補って営衛を調和し，正気が勝つ場合は，邪気は 退き，内邪は留まらず，外邪はまた入ることがない。 仲景は，表証に人参を用いない。これは半裏の無形 の証であるので, これを用いて元気を扶け, 内を調
和させて外邪を入らなくする」と述べ，小柴胡湯は 祛邪と同時に扶正の効能を備え，邪が少陽から太陰 に伝変するのを予防していると指摘しています。

（3）少陽病の病因, 病理と小柴胡湯の適応

第97条は, 少陽病の発生に病人の気血両虚が関与 することを示しています（图11）。即ち，「血弱く， 気尽き」とあるように，病人の気血が虚弱になると， 陽気が表を固めることができなくなり，その結果， 腠理が疏になって開き，風寒の邪が人体の虚に乗じ て少陽に侵入します。邪が少陽に侵入すると，邪気 と正気との間で邪正相争が引き起こされ, 胸脇苦満, 往来寒熱，黙黙として飲食を欲せずなどの少陽病の 主症が出現します。邪の侵入する部位は，「藏」即 ち肝と「府」即ち胆で上位にありますが，肝気横逆 による腹痛の部位は下位にあります。胆火が㮾滞し て胃を犯すと，喜嘔が出現します。そこで，祛邪と 同時に扶正の効能を備えた小柴胡湯を用いてこれを 治療します。

（4）小柴胡湯と戦汗

第101条は, 正気が虚した患者に小柴胡湯を投与 すると，正気が勃発し，邪正相争が強く引き起こさ れて戦汗が出現することを示しています（図12）。 戦汗は, 先ず戦慄し, 次いで汗が出ることを言い, 病人の正気が損傷されていることを示します。

小柴胡湯証が出現する場合は, 小柴胡湯を用いて 少陽を和解すべきであり，汗法，吐法，下法の使用 は禁忌ですが，これを誤下すると，正気が損傷され ます。もし誤下した後，小柴胡湯証がなお持続する 場合は，また小柴胡湯を与えます。小柴胡湯を服用 した後, 正気が薬力の助けを得て奮起して邪に抵抗 すると，先ず戦慄し，次いで熱気が沸き上がるよう に蒸蒸として発熱し, 最後に汗が出て邪が解されま す。

(5) 小柴胡湯の作用機序

第230条は，小柴胡湯の作用機序を最も端的に表 した条文です（图13）。本証は，冒頭に「陽明病」 とあるように，陽明病で発症していますが，陽明病 の症状は「大便せず」だけであり，少陽病の胸脇苦 満, 喜哣と同時に「舌上白胎」, 即ち舌苔は正常の 薄い白苔から厚い白苔に変化し，水で需らしたよう な滑苔が出現しているので, 津液が上焦に榔滞し, 水滞があることが解ります。本証は，邪の大半が少 陽にあり，邪の一部が陽明に波及していますが，ま 


\section{柴胡桂枝湯証}

傷寒六七日、発熱、微悪寒、支節煩疼、微嘔、心下 支結し、外証未だ去らざる者は、柴胡桂枝湯之を主る。 (146)

病態: 風寒の邪が太陽と少陽に侵入し、栄衛不和と少 陽枢機不利が発生する。

発熱、微悪寒、支節煩疼: 太陽の外証がまだ去つてい ない

微嘔、心下支結：軽度の少陽病の症状が持続する

\section{図15}

だ結実しておらず，燥熱は甚だしい状態ではありま せん。本証に小柴胡湯を投与した後，少陽の経気が 通じると, 胸脇苦満は消失します。三焦の気機が通 じ, 肺気が肃降して津液が上焦から中焦に下降する と，白滑苔は消失し，大便は自然に排泄されます。 大便が排泄されて胃気が調和すると，喜嘔は消失し ます。三焦が通暢し，気機が旋転すると，「身淢然 として汗出づ」とあるように，邪は絶え間なく出る 汗とともに外泄されます。

\section{7. 少陽病兼証}

(1) 大柴胡湯証

次に少陽病の兼証を幾つか打話しします。第103 条の大柴胡湯証は，少陽病に裏実証を兼称た状態に あります（図14）。本証は太陽病で発症しています が，その後十数日が経過し，邪は太陽を離れて他の 経，即ち少陽に伝変しました。少陽病は下法が禁忌 ですが，これを二三度攻下しました。その後，四五 日が経過し，小柴胡湯証がなお持続する場合は，た とえ下法の適応症があっても，先表後裏の原則に 従って先ず小柴胡湯を投与します。小柴胡湯を投与 した後，「喜嘔」が「嘔止まず」になり，「胸脇苦満」

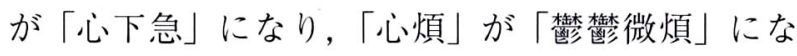
るのは，邪の一部が少陽から更に陽明に波及し，裏 実証を形成することが原因です。即ち，少陽の邪熱 が胃を犯し，胃の通降を主る機能が失調し，腑気が 通じなくなると，嘔吐は停止しなくなります。邪が 陽明に波及し，胃熱が心下に結集すると，心下が拘 急し疼痛が出現します。少陽枢機が不利になり，裏 気が塞がり, 邪熱が概滞すると, 精神は沈み, 微か な心煩が出現します。

\section{柴胡桂枝乾姜湯証}

傷寒五六日、已に汗を発して復た之を下し、胸脇满微結、小便不利、渴

して暒せず、但だ頭汗出て、往来寒熱、心煩する者は、此れ未だ解せず

と為すなり。柴胡桂枝乾姜湯之を主る。(147)

病態: 太陽病の與治によって邪が少陽に内宿し、少陽枢機が不利になり、 同時に三焦の決償を主る機能が失調して水飲が体内に停滞する。

胸縢满微結、往来寒熱、心煩: 少陽枢機が不利になる。

小便不利: 三焦の決償を主る機能が失調し、水眒が体内に停滞する。

渴す:水飲が三焦に停滞するが、上に送られなくなる

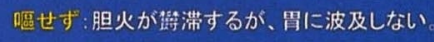

頭汗:陽気が特滞し、頭部に重蒸する

\section{図16}

大柴胡湯は, 原文では柴胡, 黄荅, 药薬, 半夏, 生姜, 枳実, 大霜の七味からなり, 方後の注では「右 七味，水一斗を以て，煮て六升を取り，滓を去り， 再煎し，一升を温服し，日に三服す。一方に，大黄 二両を加う。若し加えざれば，恐らくは大柴胡湯と 為さず」とあります。この内容からすると, 大柴胡 湯には元々 2 種類の処方があり, 一つの処方は大黄 を含まない七味からなり，もう一つの処方は大黄を 含む八味からなることが解ります。本方は小柴胡湯 の加減方であり, 小柴胡湯より人参と甘草を除き, 枳実と药薬を加えた処方ですが，一般的には陽明裏 実証の程度に応じて大黄を適宜加えて使用するとさ れています。

点謙等は, 《医宗金鑑》の中で「大柴胡湯は, 一 方に大黄がなく，一方に大黄がある。この方に大黄 を用いるのは，大黄は積もった熱を除き去る効能が あり, 傷寒の中の重要な薬物であるからである。王 叔和は, 「もし大黄を用いない場合は, 恐らくは大 柴胡湯と名づけない」と言う。かつ経文には「之を 下せば則ち愈ゆ」と明言している。もし大黄がない 場合は，何をもって心下の急を下すのであろうか」 という許叔微の説を引用し, 元々の組成に大黄を加 え，「右七味」を「右八味」に訂正しています。

一方，柯韵伯は，《傷寒来蘇集》の中で「これは, 皆少陽の半表半裏の気分の症を治療する。この方は, 三焦の無形の熱邪を治療し，胃府の有形の実邪を治

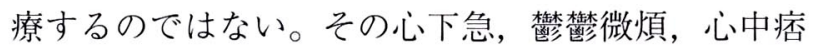
硬では，病は胃口にあるが，胃中にはなく，結熱は 裏にあるが，結実は胃にはない」と述べ，大柴胡湯 の中には元々大黄はなく, 結熱が裏にあるので, 小 


\section{柴胡加竜骨牡蚛湯証}

傷寒八九日、之を下し、胸満、煩警、小便不利、譫語 し、一身尽く重く、転側す可からざる者は、柴胡加竜骨 牡蛎湯之を主る。(107)

病態:太陽病を誤下した後、少陽枢機不利が発生し、同 時に邪が心・胃・三焦に波及し、内外の気機が阻まれる 胸満: 邪が少陽に侵入し、少陽枢機が不利になる。 煩驚: 胆火が上资し、胃熱が上蒸する。

小便不利: 三焦の決㵋を主る機能が失調する。

譄語: 邪熱が陽明の胃に入り、上昇して心神を乱す

一身尽く重く、転側す可からず: 少陽枢機が不利になり、

陽気が筑滞し、内外の気機が阻まれる。

\section{図17}

\section{少陽病の誤汗後に出現する譫語}

侮寒、脈弦細、頭痛発熱する者は、少陽に属す。少陽は汗を発す可から す。汗を発すれば則ち㴔語す。此れ胃に属す。胃和すれば則ち惫ゆ。胃和 せされば、煩して抙す。(265)

1、眽が弦細である場合は、少陽病てあるのて、汗法の使用は芸忌である

2. 少陽病专誤汗し、邪が陽明に転属して化嬠化熱し、胃熱が旺盛になる

と、諝語が出現する。

3. 津液が自然に回復し、あるいは承気湯頝を用いて実邪が去ると、涻語 は消失し、病は治癒する。

4. 陽明病を失治し、あるいは治㙩が適切でない場合は、胃㷫が更に旺盛 になるのて、心煩、心悽などの変証が発生する

\section{図19}

柴胡湯より人参と甘草を除き，心下に気機の概結が あるので，枳実と药薬を加えて破結するとしていま す。柯韵伯の解橎に立てば，「大柴胡湯証は，熱が 裏に結び，気機が根滞して腑気が通じない状態にあ るが，邪が少陽から更に陽明に波及して化燥化熱し 燥屎が形成された状態にはない」と考えられます。

\section{（2）柴胡桂枝湯証}

柴胡桂枝湯証は, 風寒の邪が太陽と少陽に侵入し， 営衛不和と少陽枢機不利が発生した状態にあります

(图15)。傷寒に罹患し，既に五六日が経過したが， 太陽の外証がまだ去っていない場合は, 発熱, 微悪 寒が出現します。本証に見られる悪寒の程度は微か であり，全身の疼痛は見られず，四肢の関節が煩わ しく痛む程度であるので, 表証はごく軽度です。支 節煩疼は，四肢の関節だけに疼痛が出現することを 言います。邪が太陽と同時に少陽に伝変すると, 微 嘔, 心下支結の症状が出現します。微嘔は, 少陽病 の主症である喜嘔に比較すると, 軽度です。また,

\section{柴胡加竜骨牡蚛湯証の譫語}

邪熱が陽明の胃に入り、上昇して心神を乱す

尤在涇:譫語するのは、邪が胃に結ぶからである。大黄は、胃気を調和し て譫語を止める。《伤寒貫珠集》

2. 少陽の邪熱が直接心に乗し、心神を乱す

哭潇等: 心煩し、第㑧し、懈語するのは、熱が心に乗し、神が不安になるか らである。《医宗金㘕》

3. 少陽の邪熱が厥院に伝わって心神を乱す。

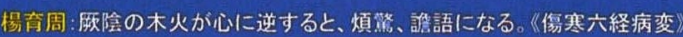

図18

\section{変証の治療原則}

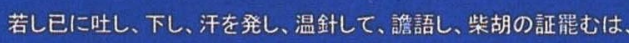
此れを壊病と為す。犯すこと何れの逆なるかを知りて、法を以て之を 治せ。(267)

1、少隄病に誤治を重ね、邪が半表半裹を雄れると、柴胡の証は消失 し、新たな堎病、即ち変証の篦語が出現する。

2. 本証に出現する譫語は変証のーつでり、同時に出現するその他 の変証は非常に多彩てあるのて、誩語が出現する病理機序を通常 の六経病変に従って単純に論しることはできない。

3. 本証の治浾は、誤治の種類を明らかにし、出現するその他の証候 に随ってこれを治療する。

\section{図20}

心下支結は，心下の幾らか外側に偏った部位が下か ら支えられるように突っ張って㾂えた感じがするこ とを言い, 少陽病の主症である胸脇苦満に比較する と，軽症です。そこで，本証は，小柴胡湯と桂枝湯 を半量づつ加えた柴胡桂枝湯を用いて治療します。

(3) 柴胡桂枝乾姜湯証

柴胡桂枝乾姜湯証は，太陽病の誤治によって邪が 少陽に内陥し，少陽枢機が不利になり，同時に三焦 の决瀆を主る機能が失調して水飲が体内に停滞した 状態にあります（図16)。傷寒に罹患して五六日が 経過し, 汗法と下法の誤治を重ね, 邪が太陽から少 陽に伝変して少陽枢機が不利になると, 胸脇満微結, 往来寒熱，心煩などの少陽病の症状が出現します。 胸脇満微結は, 胸脇の気機が微かに㮾結することを 言い, 胸脇苦満より軽症です。三焦の决瀆を主る機 能が失調し，水飲が体内に停滞すると，小便は不利 になります。水飲が三焦に停滞するが，上に送られ なくなると，口が渇きます。胆火が㮾滞するが，胃 
に波及しない場合は，嘔吐は出現しません。陽気が 鯑滞し, 頭部に熏蒸すると, 頭汗が出現します。本 証は，水飲の停滞を伴った少陽病がまだ解されてい ません。そこで, 柴胡桂枝乾姜湯を用いて治療しま す。

柴胡桂枝乾姜湯証に出現する小便不利は, 成無己 が《注解傷寒論》に「小便が不利になり口が渴くの は, 汗法と下法を使用した後, 津液を亡って内が燥 くからである」と注釈して以来, 津虚が原因である との解釈がありますが, 実際は少陽病が発生し, 水 飲が体内に停滞した状態にあります。「水飲が体内 に停滞する」という解釈は, 処方構成から推測でき ます。本方は小柴胡湯の加減方であり, 水飲が停滞 しているので, 生津助湿する人参と大棵を除きます。 また，嘔吐がないので，生姜と半夏を除きます。方 中の柴胡と黄芩は少陽を和解し, 栝樓根と牡蚛は生 津軟堅し, 桂枝, 甘草, 乾姜は中焦の陽気を振奮し て寒邪を温化します。

(4) 柴胡加龍骨牡蚛湯証

柴胡加龍骨牡蚛湯証は, 太陽病を誤下した後, 邪 が少陽に内陥し, 少陽枢機不利が発生し, 同時に邪 が心・胃・三焦に波及し, 内外の気機が阻まれた状 態にあります（图17）。邪が少陽に侵入し，少陽枢 機が不利になると, 胸満が出現します。胆火が上炎 し, 胃熱が上を熏蒸すると, 心煩, 驚悸が出現しま す。三焦の决瀆を主る機能が失調すると, 小便は不 利になります。邪熱が陽明の胃に入り，上昇して心 神を乱すと, 譫語が出現します。少陽枢機が不利に なり, 陽気が麓滞し, 内外の気機が阻まれると, 全 身が重だるくなり転側できなくなります。そこで, 柴胡加龍骨牡蚛湯を用いて治療します。

柴胡加龍骨牡蚛湯証に譫語が発生する機序につい ては，幾つかの解釈があります(图18)。尤在涇は, 邪熱が陽明の胃に入り，上昇して心神を乱すことが 原因であるとします。呉謙等は, 少陽の邪熱が直接 心に乗じ，心神を乱すことが原因であるとします。 楊育周氏は, 少陽の邪熱が厥陰に伝わって心神を乱 すことが原因であるとします。これはほんの1例で すが, 《傷寒論》の個々の証候が発生する病理機序 については，様々な説があってまだまだ検討する余 地があるように思われます。

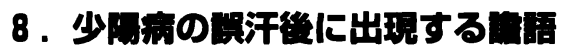

第265条は, 少陽病を誤汗した後, 邪が少陽から
陽明に転属すると，陽明病の譫語が出現することを 示しています (晜19)。この解釈は, 条文の「此れ 胃に属す」という句によって明らかにされています。 傷寒に罹患し, 脈が少陽病に特徵的な弦細になり, 側頭部に頭痛が出現し, 往来寒熱が出現する場合は, 邪は少陽にあるので, 汗法の使用は禁忌です。もし 少陽病を誤汗し, 邪が陽明に転属して化燥化熱し, 胃熱が旺盛になる場合は, 譫語が出現します。本証 は, 二種類の転機を取ります。第一の転機は, 邪が 陽明に転入した後, 津液が自然に回復し, あるいは 承気湯類を用いて実邪が去る場合であり，譫語は消 失し, 病は治癒します。第二の転機は, 陽明病を失 治し，あるいは治療が適切でない場合であり，胃熱 が更に旺盛になるので, 心煩, 心悸などの変証が発 生します。

\section{9. 变进の治主原則}

第267条は，少陽病を誤治した後に出現する変証 の治療原則を示しています（图20）。少陽病に吐法, 下法, 汗法, 温針法などの誤治を重ね, 邪が半表半 裏を離れると, 柴胡の証は消失し, 新たな壊病, 即 ち変証の譫語が出現します。本証に出現する譫語は 変証の一つであり, 同時に出現するその他の変証は 非常に多彩であるので, 譫語が出現する病理機序を 通常の六経病変に従って単純に論じることはできま せん。本証の治療は, 「犯すこと何れの逆なるかを 知りて, 法を以て之を治せ」とあるように, 誤治の 種類を明らかにし, 出現するその他の証候に随って これを治療します。即ち, 漢方の治療は, どのよう な病態ではあっても証に随って治療をすることが最 も重要であり, 今回ご紹介しました少陽病の治療も また同じであります。

\section{0. おわりに}

以上, 少陽病の病態と治療法について説明してま いりました。私は次女の喘息発作に小青龍湯を初め て投与し, その効果が西洋薬に勝るとも劣らないこ とを体験しました。これを契機として漢方の世界に 入りました私は, 《傷寒論》を学んでいく中で, 漢 方医学が実に理に適った素晴らしい治療大系である ことを知りました。大塚敬節先生は, 《臨床応用傷 寒論解説》の中で「古人は「漢方医学の研究は, 傷 寒論に始まって傷寒論に終わる」と言ったが, 私も

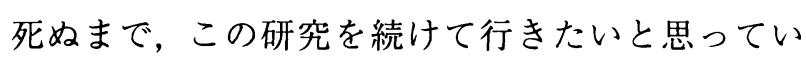
る」と述べておられます。今なお多くの先生方が《傷 
寒論》を学んでおられるのは, 条文の提示する病態 を正しく理解すれば，《傷寒論》の中に記載されて いる処方が傷寒のみならず同じ証候を呈する雑病に も有効であるからだと思われます。《傷寒論》の処 方を自在に運用するには, 《傷寒論》の個々の条文 や処方構成を細部にまで渡って完壁に理解する必要 があります。ただ，私はこの点に関してまだまだ未 熟でありますので, 大塚敬節先生のこの言葉のよう に, 今後も更に《傷寒論》を学んでまいりたいと思っ
ております。どうも，御静聴有り難うございました。 获原 先生，どうもありがとうございました。先 生が開業されて臨床をしながら，そのあとに夜，机 に向かっておられる姿が目に見えるようでございま す。先生は， 4 冊にもわたる膨大な研究の一端を， 柴胡剤を取り上げられてお話しになりました。本当 にこれからのなおいっそうのご発展を心からお祈り します。それではもう一度先生に拍手をお願いいた します。 